\title{
A Silent Attacker SARS-CoV-2 - A Review
}

\author{
Khoshnur Jannat, Nusratun Nahar, Md Shahadat Hossan, Tohmina Afroze Bondhon, Anamul Hasan, \\ Anita Paul, Rownak Jahan, Mohammed Rahmatullah
}

\begin{abstract}
The recent coronavirus (known as COVID-19 or SARS-CoV-2) has created a pandemic of unheard proportions affecting virtually every country and region of the world. As of April 15, 2020, the virus has resulted in over 2 million infections, and over 100,000 deaths and has brought world economic activities to a standstill and has led to social isolation and massive unemployment with possible economic recessions on an unprecedented scale around the corner. Till now, the virus shows no signs of abatement. Also till now, scientists have not been able to come out with an effective drug or vaccine against the virus. This review attempts to give a comprehensive view of the origin of the virus, the mode of its entry and infecting human beings, and further discusses the possibility of new drugs and vaccines against the virus.
\end{abstract}

Index Terms-COVID-19; SARS-CoV-2; coronavirus; antiviral drugs; ACE2.

\section{INTRODUCTION}

The Novel Corona Virus Disease of 2019 or COVID-19 is now counted as the worst pandemic disease after AIDS/HIV, Flu along with Asian-Flu, Cholera and Plague outbreaks. This novel (new) disease originated in Wuhan city of Hubei province of China at the end of $2019^{[1]}$. Though SARS-CoV2 first appeared in China, it has become the worst nightmare in the world with nations trying every means to bring it under control. The most affected countries with total cases of coronavirus diseased patients are given in Fig. 1. The disease spread swiftly among the people of many countries before any precautions or awareness could be made. COVID-19 virus shares $70 \%$ similarity in genetic sequence with SARS (severe acute respiratory syndrome), which became an epidemic before in 2002 [2]. The COVID-19 virus infection starts almost unnoticeably in a person and within 14 days it can cause pneumonia and other complications. Till $15^{\text {th }}$ April 2020 , total cases of corona patients in the world was $2,083,326$; total death accounted for 134,616 and recovery cases were 510,350 ${ }^{[3]}$. Till now, number of death cases are lower than recovery cases.

Still there is no cure for any corona virus diseases like SARS, MERS (Middle East Respiratory Syndrome) and COVID-19. Scientists from over the world are trying to discover drugs and vaccines. Many of the scientists are claiming the effectiveness of different drugs, but in any respect, they are effective or not is yet to be seen through appropriate clinical trials.

Published on May 17, 2020.

K. J., T. A. B., A. H., R. J. and M. R., Department of Biotechnology Genetic Engineering, University of Development Alternative, Bangladesh.

N. N. , Department of Pharmacy, Southeast University, Bangladesh.

M. S. H. , Biodiscovery Institutes, School of Pharmacy, University of Nottingham, United Kingdom.

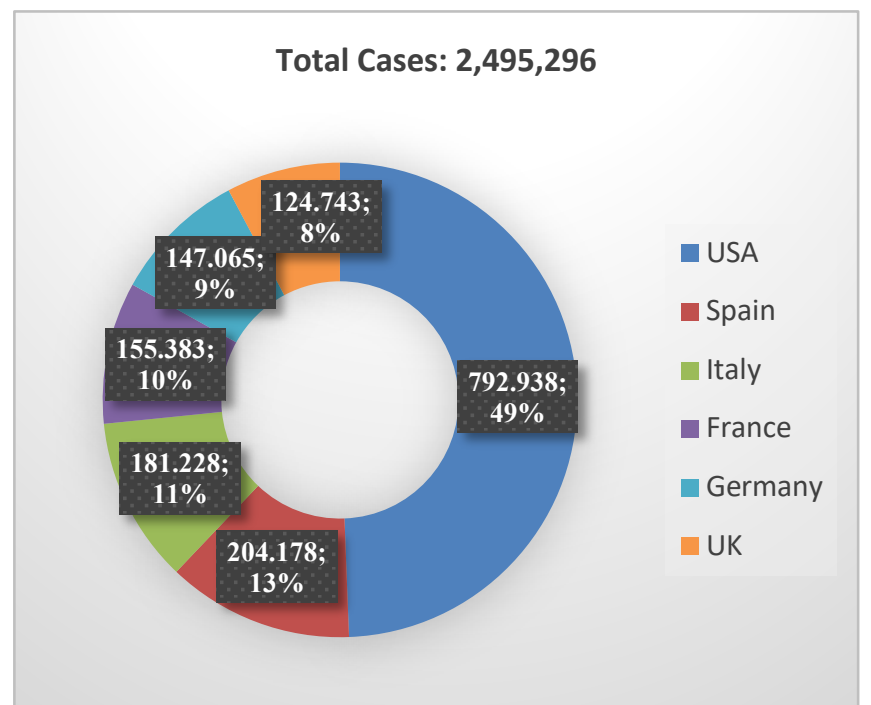

Fig. 1. COVID cases in some of the worst affected countries of the world. [Adapted from Worldometer. https://www.worldometers.info/coronavirus/. Accessed on $21^{\text {st }}$ April 2020.]

\section{COVID-19}

Corona virus can be defined based on phenotypic methods like culture, electron microscopy and serological studies. These viruses are RNA virus and have the name "corona" because of the presence of spikes on their surface which give them a crown like shape. They are an enveloped virus of 120$160 \mathrm{~nm}$ in diameter. These spherical particles contain a single stranded RNA, some essential viral proteins such as nucleocapsid protein $(\mathrm{N})$, membrane glycoprotein $(\mathrm{M})$, and spike glycoprotein (S). Two additional features are that they encode an additional glycoprotein, which has acetyl esterase and hemagglutination properties (HE), which make these viruses different from others ${ }^{[4,5,6]}$. The nucleocapsid protein (N) of corona viruses is a structural protein that has an important role in intensifying the efficiency of virus transcription and assembly. This is done by forming complexes with genomic RNA, and during virion assembly they interact with the viral membrane protein. Besides this, coronavirus $\mathrm{N}$ protein has several activities such as viral core formation, viral assembly, budding and envelope formation, genomic mRNA replication and genomic RNA synthesis, chaperon activity, cell cycle regulation, cell stress responseshost translational shutoff, viral pathogenesis-immune system interference, and signal transduction ${ }^{[7]} . \mathrm{M}$ proteins are possibly responsible for biological properties and their intracellular budding ${ }^{[8]}$. S proteins are type I membrane glycoproteins which are required for receptor binding and viral entry. These proteins contain the most variable

A. H. , Department of Pharmacy, University of Development Alternative, Bangladesh.

Corresponding Authors:

K. J. (jannat.koli.22@gmail.com) and

M. R. (rahamatm@hotmail.com) 
sequences in the virus genome and are responsible for the crown like shape of the virus. S proteins have two subunits; $\mathrm{S} 1$ subunit binds to the receptor of host cell surface and S2 subunit helps to fuse the viral and host membrane ${ }^{[9]}$.

Corona viruses are of several types which depends on varieties of host (Table I). Mainly seven types are recognized as human corona virus and they are 229E (alpha), NL63 (alpha), OC43 (beta), HKU1 (beta), MERS-CoV or MERS (Middle East Respiratory Syndrome), SARS-CoV or SARS and SARS-CoV-2 (the novel corona virus that causes corona virus disease 2019 or COVID-19) ${ }^{[10]}$. Some other corona viruses along with their respective hosts are shown in Table I [5].

Table I: Types of corona viruses along with their hosts.

\begin{tabular}{|c|c|}
\hline Viruses & Hosts \\
\hline \multicolumn{2}{|c|}{ Alpha coronavirus } \\
\hline Human corona virus $229 \mathrm{E}$ & Humans \\
\hline Human corona virus NL63 & Humans \\
\hline Transmissible gastroenteritis virus & Pigs \\
\hline Porcine respiratory coronavirus & Pigs \\
\hline Porcine epidemic diarrhea virus & Pigs \\
\hline Feline coronavirus & Cats \\
\hline $\begin{array}{c}\text { Rhinolophus bat coronavirus } \\
\text { HKU2 }\end{array}$ & Chinese horseshoe bats \\
\hline $\begin{array}{l}\text { Miniopterus bat coronavirus } \\
\text { HKU8 }\end{array}$ & Bent-winged bats \\
\hline Miniopterus bat coronavirus $1 \mathrm{~A}$ & Bent-winged bats \\
\hline Miniopterus bat coronavirus 1B & Bent-winged bats \\
\hline Scotophilus bat coronavirus 512 & Lesser Asiatic yellow house bats \\
\hline
\end{tabular}

\section{Beta coronavirus}

Subgroup A

\begin{tabular}{|c|c|}
\hline Human coronavirus OC43 & Humans \\
\hline Human coronavirus HKU1 & Humans \\
\hline Bovine corona virus & Cows \\
\hline Equine corona virus & Horses \\
\hline Mouse hepatitis virus & Mice \\
\hline $\begin{array}{l}\text { Porcine hemagglutinating } \\
\text { encephalomyelitis virus }\end{array}$ & Pigs \\
\hline \multicolumn{2}{|c|}{ Subgroup B } \\
\hline Human SARS related corona virus & Humans \\
\hline $\begin{array}{l}\text { SARS related Rhinolophus bat } \\
\text { coronavirus HKU3 }\end{array}$ & Chinese horseshoe bats \\
\hline \multicolumn{2}{|c|}{ Subgroup C } \\
\hline $\begin{array}{c}\text { Tylonycteris bat coronavirus } \\
\text { HKU4 }\end{array}$ & Lesser bamboo bats \\
\hline Pipistrellus bat coronavirus HKU5 & Japanese pipistrelle bats \\
\hline \multicolumn{2}{|c|}{ Subgroup D } \\
\hline Rousettus bat coronavirus HKU9 & Leschenault's rosette bats \\
\hline \multicolumn{2}{|c|}{ Gamma coronavirus } \\
\hline Infectious bronchitis virus & Chickens \\
\hline Turkey coronavirus & Turkeys \\
\hline Beluga whale coronavirus & Beluga whales \\
\hline \multicolumn{2}{|c|}{ Delta coronavirus } \\
\hline Bulbul coronavirus HKU11 & Chinese bulbul \\
\hline Thrush coronavirus HKU12 & Gray-backed Thrushes \\
\hline Munia coronavirus HKU13 & White-rumped Munias \\
\hline
\end{tabular}

People who have a normal immune response (immunocompetent) can suffer from common cold and selflimiting respiratory problems due to OC43, HKU1, 229E, and NL63 human coronavirus. Then again, these coronaviruses attack the lower respiratory tracts of people having an impaired immune system (immunocompromised) like mostly the elderly ${ }^{[11]}$.

\section{SARS-COV-2}

The name of coronavirus SARS-CoV-2 was given by the Coronavirus Study Group (CSG) of the International Committee on Virus Taxonomy. They gave this name based on phylogenetic analysis of related coronaviruses. SARS is a disease and the name SARS-CoV-2 is a natural extension of taxonomic practice of viruses to relate it with SARS species. Viruses of the same species can be named so whether they cause SARS like disease or not. The same applies to MERS$\mathrm{CoV}$. The name of this human coronavirus SARS-CoV-2 is already being used in the scientific articles; however, people still know it as COVID-19 [12].

\section{HOW SARS-COV-2 ATTACK HUMANS}

Viruses are intracellular parasites and they need host cells to multiply themselves. So, to do so, human SARS-CoV-2 bind to human ACE2 (angiotensin converting enzyme; a membrane protein) and enter the cells. ACE2 receptors bind with ACE2 hormone therefore raising blood pressure by constricting blood vessels. Not only the blood vessels or heart contains these receptors, but they are found all over the body to some extent. They remain abundantly in cells of tongue, esophagus, kidneys, gastrointestinal tract, lungs (mostly in alveoli), and bladder urothelial cells. So, there is a huge way open for invasion of coronavirus in human body. But coronaviruses prefer to invade through airway and attack the lungs as they are rich in ACE2 receptors ${ }^{[13-16]}$.

After invasion in the airway the viruses pass an incubation period for 5-14 days ${ }^{[17]}$. Then coronaviruses bind with ACE2 receptor and do membrane fusion to invade into the cells by using its spike protein (S). S protein has two regions, S1 does the binding with receptor and S2 helps to fuse with the cell membrane. S1 region of spike protein contains an N-terminal domain (NTD) and three C-terminal domains (CTD1, CTD2, and CTD3). SARS-CoV-2 enter to the human cell by attaching to ACE2 receptor with CTD1 domain as it is the receptor binding domain of these viruses. After entering into the cells, they start to multiply and eventually cause the destruction of the cells and suppress the immunity system ${ }^{[18-}$ 21].

So, as coronaviruses attack ACE2 receptors, there normally arises a question if people with overexpression of ACE2 receptor are at higher risk or not. Well, scientists also have found the answer. They indeed are at higher risk ${ }^{[22,23]}$.

\section{TRANSMISSION}

The viruses are zoonotic, which means they can transmit between animal and people. Not all coronaviruses can transmit from animal to human except SARS and MERS because they need close contact with infected people. The first SARS-CoV-2 patients were found to have a connection with the Hunan Seafood Market, which suggested that the coronavirus can transmit from animal to person. It is now believed that the initial source of the virus was bats with pangolins or some other animal acting as an intermediary host. Later infections were reported among the medical staffs and other who had a negative history of link with the market. This report indicated human-to-human transmission ${ }^{[25-26]}$. 
These viruses spread through air and can travel a distance of meter or possibly tens of meters. Viral particles from infected persons are transmitted through droplets when they sneeze, cough and also by contact and urine ${ }^{[27,28]}$. Droplets and aerosols can spread when infected people talk or breathe; these aerosol particles are so small, and the person is called "super-spreader" [29].

The viruses can also be transmitted through maternal-fetal interface to the fetus if the mother is infected. The maternalfetal interface is the interface which has both fetal and maternal components such fetus shares placenta and extraplacental membranes and mother shares circulation of blood others. In a study researcher found that ACE2 expression occurs in a rich amount in this interface and some body organs of fetus ${ }^{[30,31]}$. Children are found less affected by these viruses and therefore they transmit less ${ }^{[32]}$.

The viruses can remain on surface for days and in favorable atmosphere. So, if a person touches a surface with viral particles and then touches his nose, face or rub his eyes, viruses can easily enter the person's body. The viruses are found in stool and vaginal fluid as well ${ }^{[33]}$. It is also possible that the survival of the virus on different surfaces have not completely been elucidated.

\section{CLINICAL FEATURES}

Patients positive with coronavirus, show different symptoms. Common symptoms are fever, cough, fatigue, sneezing, runny nose, headache, haemoptysis, diarrhea, dyspnea, and lymphopenia. The rate of these symptoms is different in different patients ${ }^{[34]}$. In another study of 99 patients were found some more symptoms such as shortness of breath $(31 \%)$, muscle ache $(11 \%)$, confusion $(9 \%)$, sore throat $(5 \%)$, chest pain $(2 \%)$, nausea and vomiting $(1 \%)$. Comorbid conditions were also found as acute renal injury, acute respiratory injury, and septic shock ${ }^{[35]}$. In imaging of coronavirus patients including adults and children, lungs were found with interlobular thickening, ground glass opacities, adjacent pleura thickening and multifocal lung lesion ${ }^{[36,37]}$. Some other symptoms were also found such as sputum production, haemoptysis, loss of appetite, pharyngalgia and abdominal pain ${ }^{[38]}$.

\section{DIAGNOSIS}

SARS-CoV-2 remain in oropharyngea and nasopharyngea after entering the human host. Therefore, the first test to diagnose coronavirus disease must be testing the presence of viruses by taking oropharyngeal as well as nasopharyngeal swabs. Presence of viruses can also be determined by testing antibodies like IgM and for certain people, IgG in blood. Soluble CD-163 (sCD-163) that indicates presence of macrophages also can be tested ${ }^{[39,40]}$. RT-PCR or real time PCR is now a popular choice to detect SARS-CoV-2 infections ${ }^{[41]}$.

According to World Health Organization (WHO) guidelines for coronavirus disease diagnosis, detection of unique sequences of virus RNA by nucleic acid amplification tests (NAAT) is the base of routine conformation of this disease. In this case real-time reverse (rRT-PCR) polymerase chain reaction should be done. The viral genes that are targeted for tests so far are N, E, S and RdRp genes ${ }^{[42]}$.
Antigen detection tests that can detect respiratory syncytial virus (usually causes mild cold like symptoms) and influenza virus antigen by immunoassay have been also suggested to detect SARS-CoV-2. A new antigen detection test is on the horizon, which can be done by applying monoclonal antibodies against the nucleocapsid protein of SARS-CoV-2 $[43,44]$. Some other diagnostic ways can be followed such as computed tomography, checking some biomarkers which increase or decrease in SARS-CoV-2 patients (albumin, Ccreative protein, lactate dehydrogenase). Lymphopenia, leukopenia, increased erythrocyte sedimentation rate, elevated bilirubin and creatinine level, increased aspartate aminotransferase, alanine aminotransferase and creatinine kinase levels, and leukocytosis which were found in SARSCoV-2 patients can also be tested in suspect's blood to detect coronavirus ${ }^{[45,46]}$.

\section{TREATMENT}

Treatment of coronavirus patients depends on the symptoms and severity of the disease. World Health Organization (WHO) has published a guideline on treatment of coronavirus which describes about the treatment of mild, severe and critical coronavirus patients. For details following reference number "WHO/2019-nCoV/clinical/2020.4" has been suggested by WHO ${ }^{[47]}$.

Traditional Chinese medicines were practiced on coronavirus patients to some extent. Some traditional Chinese medicines were recommended by the National Health Commission of the People's Republic of China to treat coronavirus patients at different stages of the disease (Table II) ${ }^{[48]}$. Clinical trials of some formulations are ongoing such as Tan Re Qing injection, Lian Hua Qing Wen capsule/granule, Shuang Huang Lian oral liquid, Xue Bi Jing injection, Tan Re Qing capsules ${ }^{[49]}$.

Table II: Traditional Chinese Medicines Recommended by Chinese National Health Commission

\begin{tabular}{c|c}
\hline Stages of disease & Traditional medicine \\
\hline $\begin{array}{c}\text { Medical observation period } \\
\text { (MOP): fatigue with }\end{array}$ & Huo Xiang Zheng Qi Shui \\
gastrointestinal discomfort & \\
\hline Medical observation period & Lian Hua Qing Wen Capsule, Shu \\
(MOP): fatigue with fever & Feng Jie Du Capsule, Jin Hua \\
& Qing Gan Capsule \\
\hline Confirmed patients: Mild case & Qing Fei Pai Du Tang \\
\hline Confirmed patients: General case & Qing Fei Pai Du Tang \\
\hline Confirmed patients: Severe case & $\begin{array}{c}\text { Xi Yan Ping Injection, Xue Bi } \\
\text { Jing Injection, Re Du Ning }\end{array}$ \\
& $\begin{array}{c}\text { Injection, Tan Re Qing Injection, } \\
\text { Xing Nao Jing Injection, Qing Fei } \\
\text { Pai Du Tang }\end{array}$ \\
\hline Confirmed patients: Critical case & $\begin{array}{c}\text { Xue Bi Jing Injection, Re Du Ning } \\
\text { Injection, Tan Re Qing Injection, } \\
\text { Shen Fu Injection, Sheng Mai } \\
\text { Injection, Shen Mai Injection, Su } \\
\text { He Xiang Pill, An Gong Niu } \\
\text { Huang Pill }\end{array}$ \\
\hline
\end{tabular}

Different antiviral drugs have been studied since the disease appeared. Several of them used to be used for SARS treatment and rest of them for other diseases including viral diseases. Antimalarial drug hydroxychloroquine, antiviral drugs like rifampicin and oseltamivir were such drugs tested for coronavirus disease treatment ${ }^{[50]}$. A list of such drugs is given in Table III. Though Lopinavir/Ritonavir combination 
was used for early SARS-CoV-2 patients, further studies revealed that in severe case no such benefits were found from this combination ${ }^{[63,64]}$. Oseltamivir showed exacerbation of psoriasis in SARS-CoV-2-infected patients ${ }^{[65]}$. It is an open question whether using chloroquine or hydroxychloroquine for the treatment of SARS-CoV-2 is safe or not. Studies showed that use of chloroquine resulted in hemolysis and increases in oxidative injury ${ }^{[66]}$.

Table III: List of therapeutic agents that have been used in SARS-CoV2

\begin{tabular}{|c|c|c|c|c|}
\hline $\begin{array}{c}\text { Therapeutic } \\
\text { agents for } \\
\text { SARS- } \\
\text { CoV-2 }\end{array}$ & $\begin{array}{l}\text { Originally } \\
\text { used for }\end{array}$ & Mechanism & $\begin{array}{c}\text { Result in } \\
\text { SARS-CoV-2 }\end{array}$ & Ref. \\
\hline $\begin{array}{c}\text { Lopinavir/ } \\
\text { Ritonavir } \\
(\mathrm{LPV} / \mathrm{r})\end{array}$ & $\begin{array}{l}\text { HIV-1, } \\
\text { retrovirus, } \\
\text { SARS, } \\
\text { MERS }\end{array}$ & $\begin{array}{c}\text { Inhibit viral } \\
\text { replication } \\
\text { by } \\
\text { interfering } \\
\text { with } \\
\text { protease }\end{array}$ & $\begin{array}{c}\text { Decrease } \\
\text { body } \\
\text { temperature, } \\
\text { abnormal } \\
\text { amount of } \\
\text { WBC, C- } \\
\text { reactive } \\
\text { protein and } \\
\text { lymphocytes }\end{array}$ & [51] \\
\hline $\begin{array}{l}\text { Baricitinib, } \\
\text { Fedratinib, } \\
\text { Ruxolitinib }\end{array}$ & $\begin{array}{c}\text { Anti- } \\
\text { inflammato } \\
\text { ry }\end{array}$ & $\begin{array}{l}\text { Inhibition } \\
\text { of numb- } \\
\text { associated } \\
\text { kinases } \\
\text { (NAK), } \\
\text { JAK-STAT } \\
\text { signalling } \\
\end{array}$ & $\begin{array}{c}\text { In tolerated } \\
\text { doses reduced } \\
\text { viral } \\
\text { infectivity }\end{array}$ & [52] \\
\hline $\begin{array}{l}\text { Myo- } \\
\text { Inositol }\end{array}$ & $\begin{array}{c}\text { Respiratory } \\
\text { distress } \\
\text { syndrome }\end{array}$ & $\begin{array}{l}\text { Inhibition } \\
\text { of } \\
\text { interleukin } \\
6 \text { (IL-6) by } \\
\text { blocking its } \\
\text { receptor }\end{array}$ & $\begin{array}{c}\text { Reduced } \\
\text { inflammatory } \\
\text { cascade by } \\
\text { decreasing } \\
\text { IL-6 level }\end{array}$ & [53] \\
\hline Remdesivir & Ebola & $\begin{array}{c}\text { Delayed } \\
\text { chain } \\
\text { termination } \\
\text {, inhibition } \\
\text { of viral } \\
\text { RNA } \\
\text { polymerase }\end{array}$ & $\begin{array}{c}\text { Inhibited viral } \\
\text { infection (in } \\
\text { vitro) }\end{array}$ & {$[54,55,56]$} \\
\hline $\begin{array}{c}\text { Chloroquin } \\
\text { e }\end{array}$ & Malaria & $\begin{array}{l}\text { Interfere } \\
\text { the growth } \\
\text { of parasite } \\
\text { in RBC }\end{array}$ & $\begin{array}{l}\text { Antiviral } \\
\text { activity by } \\
\text { increasing } \\
\text { endosomal } \\
\mathrm{pH} \text { required } \\
\text { for virus/cell } \\
\text { fusion and } \\
\text { interfering } \\
\text { with the } \\
\text { glycosylation } \\
\text { of cellular } \\
\text { receptors of } \\
\text { SARS-CoV }\end{array}$ & {$[57,58,59]$} \\
\hline $\begin{array}{l}\text { Hydroxychl } \\
\text { oroquine } \\
\text { and } \\
\text { Azithromyc } \\
\text { in } \\
\end{array}$ & $\begin{array}{l}\text { Malaria, } \\
\text { Zika and } \\
\text { Ebla virus }\end{array}$ & $\begin{array}{c}\text { Prevent } \\
\text { respiratory } \\
\text { tract } \\
\text { infection }\end{array}$ & $\begin{array}{c}\text { Lowered viral } \\
\text { nasopharynge } \\
\text { al carriage }\end{array}$ & [60] \\
\hline $\begin{array}{l}\text { Oseltamivir } \\
\text { with } \\
\text { Lopinavir/ } \\
\text { Ritonavir }\end{array}$ & Influenza & $\begin{array}{c}\text { As } \\
\text { neuraminid } \\
\text { ase } \\
\text { inhibitor }\end{array}$ & $\begin{array}{l}\text { Recovery of } \\
\text { patients }\end{array}$ & {$[61,62]$} \\
\hline
\end{tabular}

Extracorporeal membrane oxygenation or ECMO application to severe coronavirus diseased patients lead to a dramatic recovery ${ }^{[67]}$. Some interferons (INF) such as INF $\beta 1$, INF $\alpha$, INF $\alpha 2 b$, and INF $\beta 1 b$ were found effective in combination with Lopinavir/Ritonavir ${ }^{[68]}$. Some other therapeutic agents such as Ribavirin (inhibits viral RNA dependent RNA polymerase), Umifenovir (inhibits membrane fusion of viral envelop by targeting $S$
protein/ACE2

interaction),

corticosteroids, immunomodulatory agents are also in the line for treating SARS-CoV-2 ${ }^{[69]}$.

\section{FUTURE MODES TO TREAT SARS-COV-2}

To defeat coronavirus several ways can be followed: (I) developing a vaccine, (II) designing drugs that target virus/host cell, (III) testing existing drugs, (IV) genetically engineering human T-cell using CRISPR, and (V) stem cell therapy.

Some US scientists and Australian scientists have begun working to invent a vaccine against SARS-CoV-2. Australia's Commonwealth Scientific and Industrial Research Organisation (CSIRO) have already started trials of two potential vaccines on ferrets (by nose or intramuscular injection); level of immunity will be checked. Clinical tests will be started by the end of April. Sarah Gilbert, a Professor of vaccinology along with her team at Oxford University, has developed a vaccine named "ChAdOx1nCoV-19". This vaccine has been made from chimpanzee adenovirus (a weak common cold virus), which when injected into the body, will produce antibody. Human trial is going to be held within a week. Inovio, a Pennsylvania-based pharmaceutical company has developed a DNA vaccine; by using proprietary technology, INO-4800 is injected into the body which will stimulate a particular type of immune cell ( $\mathrm{T}$ cell) and antibodies against the coronavirus [70, 71, 72]. Mesenchymal stem cells possess immunomodulatory and regenerative properties for which it has become a way for future treatment. After intravenous injection of mesenchymal stem cells to coronavirus patients these cells can give effects by recovering pulmonary microenvironment, protecting alveolar epithelial cells, arresting pulmonary fibrosis, cure lung dysfunction along with SARS-CoV-2-induced pneumonia ${ }^{[73]}$.

Scientific interest is now centering on phytochemicals, in particular flavonoids, which are said to directly inhibit the 3C-like protease of SARS-CoV-2. A recent paper has shown that three compounds, namely herbacetin, rhoifolin, and pectolinarin can efficiently block the activity of the SARSCoV-2 3C-like protease ${ }^{[74]}$

\section{Prevention}

SARS-CoV-2 spreads quite easily and swiftly. So, before going through the treatment it is important to know and maintain some preventive measures. To prevent spreading of these viruses the confirmed patients must be isolated and kept under proper treatment. Mouth covering while sneezing, coughing, trying not to touch mouth, nose, and eye before washing specially after exposure in public places, washing hand with disinfectants for several times, keeping distance from one another are the essential preventive measures. Above all boosting immunity should be prioritized first. Taking healthy immune-boosting foods can prevent from being a victim of this deadly disease ${ }^{[75]}$.

\section{CONCLUSION}

Coronavirus disease is not a very recent disease. It showed its symptoms in 2002-2003 during SARS outbreak. This virus was then called SARS-coronavirus as well and also invaded 
through lungs ${ }^{[23]}$. There is some controversy about this disease as to whether it is human produced or just an evolution of previous human coronaviruses; however, WHO position is that it is a natural coronavirus. Considering all these confusions, people are attempting to defeat this disease. But it seems the long way is yet to be walked. Still there is a hope for cure as scientists are continuously trying to combat the disease.

\section{AUTHOR CONTRIBUTIONS}

MR is guiding the COVID-related work. KJ wrote the manuscript, which was edited and approved by all the authors.

\section{ACKNOWLEDGMENT}

The authors are grateful to a number of physicians of Dhaka city for their constructive comments.

\section{CONFLICTS OF INTEREST}

The authors declare that there are no conflicts of interest.

\section{REFERENCES}

[1] Wang C, Horby PW, Hayden FG, Gao GF. A novel coronavirus outbreak of global health concern. Lancet, 2020, 395(10223):470-473. doi: 10.1016/S0140-6736(20)30185-9.

[2] Rahman S, Bahar T. COVID-19: The New Threat. International Journal of Infection, 2020, 7(1):e102184. doi: 10.5812/iji.102184.

[3] Worldometer. https://www.worldometers.info/coronavirus/. Accessed on 15 th April, 2020.

[4] Sahin AR, Erdogan A, Agaoglu PM, Dineri Y, Cakirci AY, Senel ME, Okyay RA, Tasdogan AM. 2019 Novel corona virus (COVID-19) outbreak: A review of the current literature. Eurasian Journal of Medicine and Oncology, 2020; 4(1): 1-7. doi: 10.14744/ejmo.2020.12220.

[5] Woo PCY, Huang Y, Lau SKP, Yuen KY. Coronavirus genomics and bioinformatics analysis. Viruses 2010, 2, 1804-1820; doi:10.3390/v2081803.

[6] Kannan S, Ali PSS, Sheeza A, Hemalatha K. COVID-19(Novel coronavirus 2019)- recent trends. European Review for Medical and Pharmacological Sciences, 2020, 24: 2006-2011.

[7] McBride R, Marjorie van Zyl, Fielding BC. The coronavirus nucleocapsid is a multifunctional protein. Viruses, 2014, 6(8): 2991 3018.

[8] Rottier P.J.M. (1995), The Coronavirus Membrane Glycoprotein. In Siddell S.G. (eds) The Coronaviridae. The Viruses. Springer, Boston, MA. https://doi.org/10.1007/978-1-4899-1531-3_6.

[9] Li F. Structure, function and evolution of coronavirus spike proteins. The Annual Review of Virology, 2016, 3, 237-261.

[10] Coronavirus: 7 types of human coronavirus https://en.as.com/en/2020/03/27/other sports/1585319003 056685.ht ml. Accessed on 16th April, 2020.

[11] Hassan S, Sheikh FN, Jamal s, Ezeh JK, Akhter A. Coronavirus (COVID-19): A review of clinical features, diagnosis, and treatment.Cureus 12(3): e7355. Doi:10.7759/cureus.7355.

[12] Wu Y, Ho W, Huang Y, Dong-Yan J, Li S, Shan-Lu L, Liu X, Qiu J, Sang Y, Wang Q, Kwok-Yung Y, Zhi-Ming Z. SARS-CoV-2 is the appropriate name for the coronavirus. The Lancet, 2020, 395(10228): P949-P950. Doi:https://doi.org/10.1016/S0140-6736(20)30557-2.

[13] Foley KE. The coronavirus's survival mechanism is what makes it so dangerous. QUARTZ. https://qz.com/1822554/how-the-coronavirustricks-cells-into-a-full-body-invasion/.

[14] Xu H, Zhong L, Deng J, Peng J, Dan H, Zeng X, Li T, Chen Q. High expression of ACE2 receptor of $2019-\mathrm{nCoV}$ on the epithelial cells of oral mucosa. International Journal of Oral Science 12, 8 (2020). Doi: https://doi.org/10.1038/s41368-020-0074-x.

[15] Clarke NE, Turner AJ. Angiotensine-converting enzyme 2: The first decade. International Journal of Hypertension 2012, V-2012; Art.ID307315. doi:10.1155/2012/307315.
[16] Hamming I, Timens W, Bulthuis M, Lely T, Navis G, Goor HV. Tissue distribution of ACE2 protein, the functional receptor for SARS Coronavirus. Journal of Pathology 2004, 203(2): 631-637.

[17] Lauer SA, Grantz KH, Bi Q, Jones FK, Zheng Q, Meredith HR, Azman AS, Reich NG, Lessler J. The incubation period of coronavirus disease 2019 (COVID-19) from publicly reported confirmed cases: Estimation and application. Annals of Internal Medicine 2020, doi: 10.7326/M200504

[18] He J, Tao H, Yan Y, Sheng-You H, Xiao Y. Molecular mechanisms of evolution and human infection with SARS-CoV-2. Viruses 2020, 12 428

[19] Gui M, Song W, Zhou H, Xu J, Chen S, Xiang Y, Wang X. Cryoelectron microscopy structures of the SARS-CoV spike glycoprotein reveal a prerequisite conformational state for receptor binding. Cell Res.2017, 27, 119-129.

[20] Li, W.; Moore, M.J.; Vasilieva, N.; Sui, J.; Wong, S.K.; Berne, M.A.; Somasundaran, M.; Sullivan, J.L.; Luzuriaga, K.; Greenough, T.C.; et al. Angiotensin-converting enzyme 2 is a functional receptor for the SARS coronavirus. Nature 2003, 426, 450-454

[21] Song W, Gui M, Wang X, Xiang Y. Cryo-EM structure of the SARS coronavirus spike glycoprotein in complex with its host cell receptor ACE2. PLoS Pathog. 2018, 14, e1007236

[22] Gracia-Ramos AE. Is the ACE2 overexpression a risk factor for COVID-19 infection? Archives of Medical Research 2020. doi: 10.1016/j.arcmed.2020.03.011

[23] Jia PH, Look DC, Shi L, Hickey M, Pewe L, Netland J, Farzan M, Wohlford-Lenane C, Perlman S, McCray Jr. PB. ACE2 receptor expression and severe acute respiratory syndrome coronavirus infection depend on differentiation of human airway epithelia. Journal of virology 2005, 79(23): 14614-14621.

[24] Adhikari SP, Meng S, Yu-Ju W, Yu-Ping M, Rui-Xue Y, Qing-Zhi W, Sun C, Sylvia S, Rozelle S, Raat H, Zhou H. Epidemiology, causes, clinical manifestation and diagnosis, prevention and control of coronavirus disease (COVID-19) during the early outbreak period: a scoping review. Infectious diseases of poverty 2020. 9(29). https://doi.org/10.1186/s40249-020-00646-x.

[25] Liu T, Hu J, Kang M, Lin L, Zhong H, Xiao J, He G, Song T, Huang Q, Rong Z, Deng A, Zeng W, Tan X, Zeng X, Zhu Z, Li J, Wan D, Lu J, Deng H, He J, Ma W.. Transmission dynamics of 2019 novel coronavirus (2019-nCoV). bioRxiv 2020; doi: https://doi.org/10.1101/2020.01.25.919787.

[26] ] Li Q, Guan X, Wu P, Wang X, Zhou L, Tong Y, et al. Early transmission dynamics in Wuhan, China, of novel coronavirus-infected pneumonia. The New England Journal of Medicine. 2020 https://doi.org/10.1056/NEJMoa2001316.

[27] He Y, Zheng C. Replication and transmission mechanisms of highly pathogenic human coronaviruses. Zheijiang Da Xue Xue Bao YiXue Ban 2020, 49(1). https://www.ncbi.nlm.nih.gov/pubmed/32298055.

[28] Morawska L, Cao J. Airborne transmission of SARS-CoV-2: The world should face the reality. Environment International 2020. 139:105730. doi: 10.1016/j.envint.2020.105730.

[29] Meselson M. Droplets and Aerosols in the transmission of SARS-CoV2. The New England Journal of Medivine 2020. doi: 10.1056/NEJMc2009324.

[30] Shivhare SB, Lash EG. Chapter114- Immunity at the maternal-fetal interface. Mucosal Immunology (Fourth Edition) 2015, 2: 2231-2250.

[31] Li M, Chen L, Zhang J, Xiong C, Li X. The SARS-CoV-2 receptor ACE2 expression of maternal-fetal interface and fetal organs by single cell transcriptome study. PLoS One 2020, 15 (4): e0230295. doi: 10.1371/journal.pone.0230295

[32] de Niet A, Waanders BL, Walraven I. The role of children in the transmission of mild SARS-CoV-2 infection. Acta Paediatrica 2020. doi: 10.1111/apa.15310

[33] Singhal T. A review of coronavirus disease-2019 (COVID-19). The Indian Journal of Pediatrics 2020. https://doi.org/10.1007/s12098-020 03263-6.

[34] Huang C, Wang Y, Li X, Ren L, Zhao J, Hu Y, Zhang L, Fan G, Xu J, Gu X, Cheng Z, Yu T, Xia J, Wei Y, Wu W, Xie X, Yin W, Li H, Liu M, Xiao Y, Gao H, Guo L, Xie J, Wang G, Jiang R, Gao Z, Jin Q, Wang J, Cao B. Clinical features of patients infected with 2019 novel coronavirus in Wuhan, China. Lancet 2020, 395(10223):497-506. doi: 10.1016/S0140-6736(20)30183-5.

[35] Chen N, Zhou M, Dong X, Qu J, Gong F, Han Y, Qiu Y, Wang J, Liu Y, Wei Y, Xia J, Yu T, Zhang X, Zhang L. Epidemiological and clinical characteristics of 99 cases of 2019 novel coronavirus pneumonia in Wuhan, China: a descriptive study. Lancet 2020, 395(10223):507-513. doi: 10.1016/S0140-6736(20)30211-7.

[36] Xu X, Yu C, Qu J, Zhang L, Jiang S, Huang D, Chen B, Zhang Z, Guan W, Ling Z, Jiang R, Hu T, Ding Y, Lin L, Gan Q, Luo L, Tang X, Liu J. Imaging and clinical features of patients with 2019 novel coronavirus 
SARS-CoV-2. European Journal of Nuclear Medicine and Molecular Imaging 2020, 47(5):1275-1280. doi: 10.1007/s00259-020-04735-9.

[37] Xia W, Shao J, Guo Y, Peng X, Li Z, Hu D. Clinical and CT features in pediatric patients with COVID-19 infection: Different points from adults. Pediatric Pulmonology 2020, 55(5):1169-1174. doi: 10.1002/ppul.24718.

[38] Jiang F, Deng L, Zhang L, Cai Y, Cheung CW, Xia Z. Review of the clinical characteristics of coronavirus diseases 2019 (COVID-19). Journal of General Internal Medicine 2020, doi: 10.1007/s11606-020 05762-w.

[39] Shoenfeld Y. Corona (COVID-19) time musing: Our involvement in COVID-19 pathogenecies, diagnosis, treatment and vaccine planning. Autoimmunity Reviews 2020, $102538 . \quad$ doi: 10.1016/j.autrev.2020.102538

[40] Kokkinakis I, Selby K, Favrat B, Genton B, Cornuz J. Covid-19 dagnosis: clinical recommendations and performance of nasopharyngeal swab-PCR. Revue Medicale Suisse 2020 16(689):699-701.

[41] Unhale SS, Ansar QB, Sanap S, Thakhre S, Wadatkar S, Bairagi R, Sagrule S, Biyani KR. A review on coronavirus (COVID-19). World Journal of Pharmaceutical and Life Sciences 2020, 6(4): 109-115.

[42] World Health Organization. (2020). Laboratory testing for coronavirus disease 2019 (COVID-19) in suspected human cases: interim guidance, 2 March 2020. https://apps.who.int/iris/handle/10665/331329

[43] Sheridan C. Fast, portable tests come online to curb coronavirus pandemic. Nat Biotechnol. 2020. [PMID: 32203294] doi:10.1038/d41587-020-00010-2.

[44] Prendergast C, Papenburg J. Rapid antigen-based testing for respiratory syncytial virus: moving diagnostics from bench to bedside? Future Microbiol. 2013;8:435-44. [PMID: 23534357] doi:10.2217/fmb.13.9.

[45] Cheng MP, Papenburg J, Desjardins M, Kanjilal S4, Quach C, Libman M, Dittrich S, Yansouni CP. Diagnostic testing for severe acute respiratory syndrome-related coronavirus-2: a narrative review. Annals of Internal Medicine 2020, doi: 10.7326/M20-1301.

[46] Zhang Z, Shen Y, Wang H, Zhao L, Hu D. High-resolution computed tomographic imaging disclosing COVID-19 pneumonia: a powerful tool in diagnosis. The Journal of Infection 2020, pii: S01634453(20)30178-X. doi: 10.1016/j.jinf.2020.03.047.

[47] World Health Organization 2020. Clinical management of severe acute respiratory infection when COVID-19 is suspected. 13 March, 2020. Reference Number: WHO/2019-nCoV/clinical/2020.4 https://www.who.int/publications-detail/clinical-management-ofsevere-acute-respiratory-infection-when-novel-coronavirus-(ncov)infection-is-suspected.

[48] National Health Commission of the People's Republic of China. Notice on the issunance of guidelines of diagnosis and treatment for 2019. nCoV infected pneumonia (version 6). 6 ed http://www.nhc.gov.cn/yzygj/s7653p/202002/8334a8326dd94d329df3 51d7da8aefc2.shtml?from=timeline. 2020.

[49] Yang Y, Islam SM, Wang J, Li Y, Chen X. Traditional Chinese Medicine in the Treatment of Patients Infected with 2019-New Coronavirus (SARS-CoV-2): a Review and Perspective. International Journal of Biological Sciences 2020; 16(10): 1708-1717. doi: $10.7150 /$ ijbs. 45538 .

[50] Mitza O, Clotet B. Use of antiviral drugs to reduce COVID-19 transmission. The Lancet Global Health 2020, DOI:https://doi.org/10.1016/S2214-109X(20)30114-5.

[51] Ye XT, Luo YL, Xia SC, Sun QF, Ding JG, Zhou Y, Chen W, Wang XF, Zhang WW, Du WJ, Ruan ZW, Hong L. Clinical efficacy of lopinavir/ritonavir in the treatment of coronavirus disease 2019 European Review for Medical and Pharmacological Sciences 2020 , 24(6):3390-3396. doi: 10.26355/eurrev_202003 20706.

[52] Stebbing J, Phelan A, Griffin I, Tucker C, Oechsle O, Smith D, Richardson P. COVID-19: combining antiviral and anti-inflammatory treatments. The Lancet Infectious Diseases 2020, 20(4): P400-402.

[53] Bizzarri M, Laganà AS, Aragona D, Unfer V. Inositol and pulmonary function. Could myo-Inositol downregulate inflammation and cytokine release syndrome in SARS-CoV-2? European Review for Medical and Pharmacological Sciences 2020, 24(6):3426-3432. doi: 10.26355/eurrev 20200320715.

[54] Tchesnokov PE, Feng JY, Porter DP, Götte M. Mechanism of inhibition of ebola virus RNA-dependent RNA polymerase by remdesivir. Viruses 2019, 11(326). doi:10.3390/v11040326.

[55] Wang M, Cao R, Zhang L, Yang X, Liu J, Xu M, Shi Z, Hu Z, Zhong W, Xiao G. Remdesivir and chloroquine effectively inhibit the recently emerged novel coronavirus (2019-nCoV) in vitro. Cell Research 2020 30(3): 269-271. doi: 10.1038/s41422-020-0282-0.

[56] Grein J, Ohmagari N, Shin D, Diaz G, Asperges E, Castagna A et.al. Compassionate use of remdesivir for patients with severe COVID-19.
The New England Journal of Medicine 2020, doi: 10.1056/NEJMoa2007016.

[57] Gao J, Tian Z, Yang X. Breakthrough: Chloroquine phosphate has shown apparent efficacy in the treatment of COVID-19 associated pneumonia in clinical studies. Bioscience Trends 2020, 14(1):72-73. doi: $10.5582 /$ bst.2020.01047

[58] Moore, N. Chloroquine for COVID-19 Infection. Drug Safety 43, 393394 (2020). https://doi.org/10.1007/s40264-020-00933-4

[59] Slater AF. Chloroquine: mechanism of drug action and resistance in Plasmodium falciparum. Pharmacology Therapy 1993, 57(2-3): $203-$ 235. Doi: 10.1016/0163-7258(93)90056-j.

[60] Gautret et al. (2020) Hydroxychloroquine and azithromycin as a treatment of COVID-19: results of an open-label non-randomized clinical trial. International Journal of Antimicrobial Agents - In Press 17 March 2020 - DOI : 10.1016/j.ijantimicag.2020.105949.

[61] Jiun-Ji S, Jim-Min F. Development of effective anti-influenza drugs: congeners and conjugates- a review. The Journal of Biomedical Science 2019, 26:84, doi: 10.1186/s12929-019-0567-0.

[62] Costanzo M, De Giglio MAR, Roviello GN. SARS CoV-2: Recent Reports on Antiviral Therapies Based on Lopinavir/Ritonavir, Darunavir/Umifenovir, Hydroxychloroquine, Remdesivir, Favipiravir and Other Drugs for the Treatment of the New Coronavirus. Current Medicinal Chemistry 2020, doi: 10.2174/0929867327666200416131117.

[63] Cao B, Wang Y, Wen D, Liu W, Wang J, Fan G, et.al. A trial of lopinavir-ritonavir in adults hospitalized with severe COVID-19. The New England Journal of Medicine 2020, DOI: 10.1056/NEJMoa2001282.

[64] Baden LR and Rubin EJ. Covid-19 - The search for effective therapy. The New England Journal of Medicine 2020 Mar 18; [e-pub] (https://doi.org/10.1056/NEJMe2005477).

[65] Kutlu Ö, Metin A. (2020). A case of exacerbation of psoriasis after oseltamivir and hydroxychloroquine in a patient with COVID-19: Will cases of psoriasis increase after COVID-19 pandemic? Dermatologic Therapy, e13383. doi:10.1111/dth.13383.

[66] Kassi EN, Papavassiliou K A, Papavassiliou AG. (2020). G6PD and chloroquine: selecting the treatment against SARS-CoV-2? Journal of Cellular and Molecular Medicine. doi:10.1111/jcmm.15312.

[67] Zhan WQ, Li MD, Xu M, Lu YB. Successful treatment of COVID-19 using extracorporeal membrane oxygenation, a case report. European Review for Medical and Pharmacological Sciences 2020, 24(6):33853389. doi: 10.26355/eurrev_202003_20705.

[68] Sallard E, Lescure FX, Yazdanpanah Y, Mentre F, Peiffer-Smadja N. Type 1 interferons as a potential treatment against COVID-19. Antiviral Research 2020, 178:104791. doi: 10.1016/j.antiviral.2020.104791.

[69] Sanders JM, Monogue ML, Jodlowski TZ, Cutrell JB. Pharmacologic Treatments for Coronavirus Disease 2019 (COVID-19): A Review. JAMA. Published online April 13, 2020. doi:10.1001/jama.2020.6019.

[70] Gallagher J. Coronavirus: Are we getting closer to a vaccine or drug. BBC News. https://www.bbc.com/news/health-51665497. Accessed on 20 th April, 2020.

[71] Ryan J. Coronavirus treatments: hydroxychloroquine, vaccines and drugs for COVID-19. https://www.cnet.com/how-to/coronavirustreatments-hydroxychloroquine-vaccines-and-drugs-for-covid-19/. Accessed on 20th April, 2020.

[72] Medscape. Oxford COVID-19 Vaccine Trial 'Within Weeks' : Q\&A. https://www.medscape.com/viewarticle/928941. Accessed on 21th April, 2020.

[73] Golchin A, Seyedjafari E, Ardeshirylajimi A. Mesenchymal stem cell therapy for COVID-19: present and future. Stem Cell Reviews and Reports 2020, doi: 10.1007/s12015-020-09973-w.

[74] Jo S, Kim S, Shin DH, Kim M.-S. Inhibition of SARS-CoV 3CL protease by flavonoids. Journal of Enzyme Inhibition and Medicinal Chemistry 2020, 35(1):145-151. https://doi.org/10.1080/14756366.2019.1690480.

[75] Shen K, Yang Y, Wang T, Zhao D, Jiang Y, Jin R, Zheng Y et.al Diagnosis, treatment and prevention of 2019 novel coronavirus infection in children: expert's consensus statement. World Journal of Pediatrics 2020, DOI: 10.1007/s12519-020-00343-7. 